\title{
Intangibles Disclosure Information on Internet by Multinational Corporations
}

\author{
Juan L. Gandía. University of Valencia. Spain. \\ Juan.L.Gandia@uv.es
}

\begin{abstract}
Rapid developments in information and communications technology, especially with regard to Internet, have caused a substantial impact on the delivery and dissemination of business information. Internet reporting is expected to bring significant benefits to reporting companies, including facilitating access to potential investors an other stakeholders, disseminating information more quickly, more widely and at less cost, providing a platform to integrate different technologies and reducing the cost of providing hard copy annual reports. In this paper, we have examined the extent and the way companies use Internet to provide information about their intangibles. We have established for the Standard \& Poor's GLOBAL 100 Index companies, different Internet intangibles disclosure indexes, and we have contrasted which variables explain the disclosure of this intangible information on Internet. Results show that the region of origin, especially in the European companies, and the intensity of the intangible expenditures are the main factors that explain the differences in the extent of corporate intangible disclosure on Internet.
\end{abstract}

Key words: Internet; Intangibles; Disclosure Index; Corporate Reporting; Multinationals.

\footnotetext{
1 This paper was made possible by financial support from Spanish Ministry of Science and Technologies. Research project BEC2001-3356
} 


\section{INTRODUCTION}

The ways in which business is conducted continue to change and, given this evolution, there will be fundamental changes in business reporting. Nowadays, general trends in corporate information focus on the growing importance of nonfinancial and qualitative information, particularly social and environmental information, with a greater focus on prediction rather than historical data. More specifically, some experts predicted an increasing use of share price performance graphs and intangibles (Xiao et al., 2002: 255). Thus, we are attending a change in the businesses' model, which is mainly influenced by technology, especially by the Internet.

The growth of the Internet as a medium for delivering business reporting information has altered the way information flows from companies to investors and creditors. That structure will continue changing as companies bring new technologies to the process, and as information users find new ways to gather and analyze information. Corporate Web sites are designed for multiple reasons, including advertising the firm's products, facilitating electronic commerce, promoting brand identification, attracting potential employees, and enhancing the corporate image. Besides, corporate leaders see the potential for the voluntary disclosures to improve investors' relations and capital market efficiencies, for example by the posting of business and financial information (Lybaert, 2002).

In this context, there is a number of studies that make a descriptive analysis about the type of financial information that companies disclose through Internet. Nevertheless, no research has investigated the Internet possibilities as channel to communicate the companies intangibles information. For this reason, in this paper, the main purpose is to examine and explore which use companies do and which variables explain the disclosure of information about intangibles by the use of the internet.

The remainder of the paper proceeds as follows: Section 2 discusses the problematic about business reporting model and intangibles reporting. Section 3 deals with the prior literature about corporate reporting on Internet. In section 4 our research methodology to determine the Internet intangibles disclosure indexes, and an explanatory model of Internet intangibles disclosure levels are presented. 
This section is also about our research results and the hypothesis tested. The final section contains a summary of the paper and some conclusions.

\section{BUSINESS REPORTING MODEL AND INTANGIBLES}

During the last two decades, a myriad of authors have insisted that major parts of the world economy have transformed from a traditional financial to a knowledge-based economy (see Cañibano et al., 2000). The accounting consequences of the knowledge-based economy and the diminishing value relevance of financial as well as management accounting have created new opportunities (and threats) for the accounting branch. A number of new accounting concepts have emerged, some of which could be regarded as an evolutionary elaboration of traditional accounting (Roslender, 1997).

In this sense, traditional financial reporting model has been criticised because it has not evolved at the same rate as business changes. In fact, the initiative of regulating organizations, businesses, investors, analysts and users in general has progressively modified the conception of which information should be provided in order to face the real needs of its different users. Different studies, as those carried out by AICPA (1994), ICAEW (1998a, 1998b, 1999) or FASB (2001b), have also shown that business reporting should evolve to minimize this gap.

The shift to a knowledge-based economy has created, or focused, increased attention on entirely different categories of resources. Intangible resources, such as brand names, intellectual capital, patents, copyrights, expenditures for research and development and human resources, are generating an increasing amount of our overall wealth.

The problem, according with Meer-Kooistra and Zijltra (2001), is that reporting externally on intangibles assets has its own requirements. The external stakeholders expect that they can compare the companies' reports. This requires standardization of the information. They further expect that the information is reliable and objective, and that all those possibilities of window dressing and subjectivity are ruled out. The quality of the information (including standardization, reliability, objectivity) can be guaranteed by demanding an independent assessment of the information. 
There exist big differences between the underlying assumptions of an intangibles reporting and those of the traditional annual statement. The traditional financial accounting framework is based on a backward looking perspective, and only uses financial measures, which allows calculation and a bottom-line result. The assumptions underlying the intangibles reporting framework are in conflict with the financial accounting standards, since these prohibit the recognition of intangible assets in many circumstances. However, those accounting prohibitions do not obviate their existence nor their importance, and the information disclosed about them is rather seen as especially helpful for investors in taking investment decisions (FASB, 2001a). This conclusion becomes significantly relevant if we consider that several empirical evidences have shown that non-accounting of intangible assets can be one reason to the continuous fall in the value relevance of financial accounting during the past 25 years (see Aboody and Lev, 1998; Francis and Schipper, 1999; Lev and Zarowin, 1999, among others).

In response to this information gap or lack of understanding, many concepts and measurement models have been suggested over the years. In the 1990s different models were propounded, including the balanced scorecard (Kaplan and Norton, 1992), intellectual capital (Edvinsson and Malone, 1997) and the intangible assets monitor (Sveiby, 1997). According to Johanson et al. (2001), a common feature of these models is that although they still rely on measurements, financial information is only looked upon as one element of the information which is needed. Because of this feature of the models, they are often addressed as non-financial model. Up to now, rigorous scientific investigations on the consequences of the adoption of these non-financial models have not been carried out (Johanson et al., 1999).

The design of these models is a hard task because "intangibles" has no generally accepted definition. Cañibano and Sánchez (1998) state that the adjective "intangible" normally accompanies different concepts, such as assets, investments, resources, or other phenomena. This diversity is also present in international context (Stolowy and Jeny-Cazavan, 2001). In fact, over the years, numerous definitions and classifications of intangibles have been proposed, particularly during the last decade. The various definitions or classifications of intangibles will not be discussed in this paper (see Johanson et al., 1999; Gröjer, 2001). 
In any case, users of financial statements will want more transparency, which means more information about the things they cannot see on a traditional balance sheet. All this point to the desirability of having policies that govern how intangible assets are managed, measured and reported. A coherent policy for the reporting of intangible assets would facilitate consistency and also help to discharge more comprehensively the stewardship responsibilities that are part and parcel of being a manager (see Guthrie et al., 2001).

In this context, it is necessary to ask him how and where the intangible information for the companies should be presented and reproduced (see Petty and Guthrie, 2000: 169). Nowadays, the information technology, especially the Internet, offers different possibilities to disclose business information, and intangible information. The characteristics of Internet reporting mesh well with broader changer occurring in the business environment, in particular, the shift towards consumer-driven business and the increasing importance of "soft" assets such as intellectual capital (Beattie and Pratt, 2001). Stakeholders today want "data on demand" using technology formats that allow quick access and analysis to help make better decisions. As the FASB (2000) sustains, the availability of more timely and relevant information should help increase the efficiency of capital markets. In consequence, we try to verify if the companies use Internet to disclose their information on intangibles, and what variables explain this behavior.

\section{CORPORATE REPORTING ON THE INTERNET}

Technology advances have revolutionised the way information is exchanged and the way business is conducted. The Internet allows information to move quickly and easily all over the world and makes information accessible at any time, in any place, to anyone with Internet access ${ }^{2}$. Internet technologies are now widely used within businesses as the basis of internal corporate communications, and open Internet standards are now a key element of any IT platform. As a result there is an ongoing transformation in the way business is conducted and regulated, and

\footnotetext{
2 According to the Computer Industry Almanac data, in December 2002 the estimated number of world wide Internet users was 665 million people, of which 24\% were American. The proportions in other countries were as follows: Japan (10\%), Germany (8\%), China (6\%), United Kingdom (4\%), South Korea (4\%), Canada $(3 \%)$, France $(3 \%)$, Italy $(3 \%)$ or Spain (2\%). For a detailed breakdown of these and other statistics related to Internet consult the following electronic address: [http://www.c-i-a.com/].
} 
whilst this leads to opportunities there are also new risks to be managed. The onslaught of the information revolution has profound ramifications for corporate reporting, for both preparers and users of this information (Willis et al., 2002).

Today, many companies, regardless of size, make information available to the public through Internet Web sites. On those sites and through links from one Web site to others, individuals may obtain a vast amount of information in few seconds. Advanced data presentation methods using audio, video, and graphic and image material are now available through even the most inexpensive personal computers and laptops (FASB, 2000).

According with Lybaert (2002: 196), the Web offers a low cost solution to access of corporate data by using an established network structure which all can easily participate in, and this at convenient times for those users. Besides the access to greater volumes of data than were previously possible, the Internet is potentially useful by providing flexibility in user models of data, hypermedia delivery of data, as well as possibilities for exporting data for user manipulation. So the Internet allows users more easily to relate financial information to nonfinancial information, makes financial information more readily accessible to nonaccounting users, makes available the latest information on a company, offers an efficient way for investors/viewers to give the company comments and feedback and improves equality of information access ${ }^{3}$.

In this sense, the US Securities and Exchange Commission adopted in august 2002 new disclosure regarding access to reports on company Web sites. These rules consider that one of the key benefits of the Internet is that companies can make information available to many financial markets more quickly and in a less cost-effective manner. Online access to Internet information also helps to democratization of the capital markets by enabling many small investors to have access to corporate information (SEC, 2002).

Nevertheless, although potential motives for companies to provide financial and non-financial information on the Internet, they may be identified as a range of factor that may constrain the realization of this potential (Xiao et al., 2002).

\footnotetext{
3 In this sense, Wallman (1997) proposed a disaggregated, user controlled "access" model, that Internet will facilitate the provision of raw data to users. Nonetheless, the opinions from seventeen UK experts in accounting and/or the Internet, suggested that the users are either already overloaded or, in many cases, lack the skills to make use or raw data (see Xiao et al., 2002).
} 
Among the factors suggested stand out, i) the motivation for the adoption of Internet reporting (provide data to many types of audiences, marketing purposes, "bandwagon" effect), ii) the lack of regulatory involvement (regulators' passivity may intensify fears to the credibility of Internet reporting), and iii) the little demand for Internet reporting except as an alternative, more timely, distribution medium for the existing hard copy annual report.

Empirical evidence has demonstrated that a high percentage of companies use Internet for electronic dissemination of business reporting information. Generally, the proportion of the companies considered in these studies which disclose their business reporting information on the Internet ranges between 100\% in the case of US companies (Gray and Debreceny, 1997; Ashbaugh et al., 1999; FASB, 2000), rather more than 50\% for the United Kingdom (Lymer, 1997) and Holland (Lybaert, 2002), and less for countries such as Finland (Lymer and Tallberg, 1997), Sweden (Hedlin, 1999) or Spain (Gowthorpe and Amat, 1999; Gandía, 2001; Larrán and Giner, 2002). Some empirical comparative studies have also been carried out at a national level (see Deller et al., 1999; Lymer et al., 1999; Trites, 1999; Bonsón and Escobar, 2002). This overview of literature should not be considered as comprehensive. Besides the references made in the reports of the FASB (2000) and Lymer et al. (1999), a good overview of former studies is given in Lymer (1999), Larrán and Giner (2002) and Xiao et al. (2002).

In any case, these studies stress the potential that Internet has as a useful mechanism for improving the communication between the companies which have generated the financial (or not financial) information and its potential users. This characteristic explains our interest in the analysis of the main multinational companies' commitment for disclosing the information which is not available in the traditional financial statement, especially the one related to intangible assets.

\section{INTERNET INTANGIBLES DISCLOSED BY MULTINATIONAL CORPORATIONS}

\subsection{Internet Intangibles Disclosure Indexes}

The application of indexes is a habitual practice in researches about the level and extent of business information disclosure. They have been particularly applied in voluntary disclosure studies (see Cooke, 1989; Hossain et al., 1995; Meek et al., 1995; Botosan, 1997; Depoers, 2000; Bhojraj et al., 2000, among others). The 
methodology of these studies can be applied to ours if we consider that the dissemination of information through Internet is voluntary for companies (see, among others, Ettredge et al., 1999a; Pirchegger and Wagenhofer, 1999; Craven and Marston, 1999; Lybaert, 2002; Bonsón and Escobar, 2002; Larrán and Giner, 2002).

To determine the nature of the information related to intangibles disclosed on Internet by the companies, we have established an index based on Ettredge et al. (1999a), Pirchegger and Wagenhofer (1999) and Gandía (2001). For the definition of the proposed index, we have grouped in three categories those questions which may configure the opinion of any potential user of the web pages on the companies' ability to increase their value through the management of their intangibles (see figure 1). These three categories are as follows:

1. ConTENTS. In this category, we have examined if companies have incorporate information about their intangible assets in their Web sites. But previously, it has been necessary to detail the intangible assets that we have considered in the study of the "contents".

In this sense, several possible classifications of the intangible assets have been proposed by accounting literature (see Johanson et al., 1999; Gröjer, 2001). As reference, we have taken the classifications considered by Lev (2000), by the University of New York Centre of Investigation into Intangible Assets ${ }^{4}$, and by the Skandia Navigator model ${ }^{5}$. The election of these classifications owes, first, to the prestige and international recognition that they have. Second, because they facilitate the obtaining of the information of the Web sites companies.

However, and despite of it, we want to expose that this election has been one of the most difficult and problematic aspects we have faced in the study of this category. These prior steps have allowed us to structure the aspects related to intangible assets in four sections.

The first section includes information related to the company's capacity for innovation and commercialisation. Here, we have drawn a special attention to the $R \& D$ investments. In fact, we have not only considered the economic amount of this item, but we have also pointed out other qualitative aspects that showed a clear firm's innovative attitude.

\footnotetext{
4 [http://www.stern.nyu.edu/ross/ProjectInt/].

5 [http://www.skandia.com]
} 


\section{CONTENTS INTERNET INDEX (IC)}

INNOVATION INDEX (IN)

1. R\&D investment in 1999 (1 point); previous years ( +1 point)

2. Information about the "intensity" of $\mathrm{R} \& \mathrm{D}$ investment ( $R \& D$ to Sales)

3. Information $R \& D$ projects underway

4. Description of available $R \& D$ centres

5. Collaboration with centres of basic investigation

6. Patents filed in 1999 ( 1 point); previous exercises ( +1 point)

7. Marks registered in 1999 (1 point); previous exercises ( 1 point)

8. Sales licences conceded in 1999 (1 point); previous exercises $(+1$ point)

9. Royalty income in 1999 (1 point); previous exercises $(+1$ point)

\section{HuMAN ResourCes INDEX (IHR)}

1. Number of company employees

2. Proportion of graduates employed

3. Proportion of scientifically trained members of staff

4. Existence of staff training plans (1 point); if annual cost is given (+1 point)

5. Internal promotion plans

6. Employee benefit plans
7. Description of recruitment and selection processes

8. Mean age of workforce

9. Mean seniority of workforce

\section{Customers_INDEX_(ICS)}

1. Information about the products commercialised by the company

2. Dimensions and characteristics of branch network

3. Product quality control information

4. Information about guarantees offered

5. Integral after-sales service

6. Company "philosophy"

\section{NETWORKING INDEX (INTW)}

1. Strategic alliance information

2. Dimension and characteristics of distribution network

3. Collaboration agreements with other companies for the development of products and services

4. Use of B2B

5. Investment in e-business

\section{NAVIGATION INTERNET INDEX (INVT)}

1. Existence of a innovative and commercialisation information section

2. Existence of a human resources section

3. Existence of a information customers section

4. Existence of a networking information section
5. Existence of a "late news" of the company

6. Accessibility in various languages

7. Availability of links to analyst reports or news about the company featured in the press

\section{DESIGN-ACCESSIBILITY INTERNET INDEX (IDA)}

1. Structured appearance

2. Good colour, graphics and image combination

3. Use of advanced languages (Java, XML) to facilitate presentation
4. Inclusion of support graphics or images for the presentation of financial data 5. Facilitate an e-mail address through which to contact the company

Figure 1. Checklist of individual items of Internet intangibles disclosure indexes 
The same attention has been placed on other positive data as the patents filed, the registered marks, or the sales licences obtained by the company ${ }^{6}$. However, if these information were referred to a period of several years, it would bring the possibility to evaluate the company's innovative tendency.

The second section presents information related to those human resources which are part of the organisation. Most information shown here has been collected from the Skandia Navigator model, but we have also taken into account some qualitative data. We have considered highly relevant the information about the existence of training plans within the company (and where possible, their annual cost), the internal promotion schemes, the employee benefit plans (pension health, family, housing plans, etc.) or the mean seniority of the workforce. All of these factors have been interpreted as indicators of the quality and satisfaction that employees need to carry out efficiently their tasks. Their consideration should provide an improved knowledge of the real capacities of the companies to generate additional value and economic performance. In the same way, the description of staff recruitment and selection processes, the proportion of graduates and scientifically qualified members of staff, and the mean age of the workforce will give us an image of the company's ability to affront changes in the complex business world.

In the third section, we have analysed any information referred to customers. Undoubtedly, a correct management of the information about customers gives relevant competitive advantages, mainly in the current business environment. In this sense, the knowledge of the product or service commercialised by the company has been taken into account, even if it was not submitted to any quality controls. The information about the branch networks, or the evaluation of their after-sales services, or other guarantees that the company offers, presents a significant interest. In fact, it reflects a measure of the accuracy and seriousness the company has added to the development of its products or services. Finally, we have also observed in this section if the description of the company's philosophy was provided. This

\footnotetext{
6 The need of companies to increase their informative flows related to the investigations they carry out has increased in the last few years. This is due to a change in the mentality of the companies, which have just began to note that the development of a product or service is not necessarily a defense mechanism directed against the competition but rather an economically viable tool (Arora et al., 2000). This change observed has led us to include the incomes obtained from royalties as a variable to analyse. Even if they are not recognised individually in the statements, investors consider them a relevant data to investors, as noted Gu and Lev (2000).
} 
kind of information is also useful because it helps to outlook the company's attitudes in regard to certain subjects as, for example, the environment, the health, the quality of life, racial or sexual discrimination. In other words, it summarises the image the company projects to the society.

In the fourth and last section, we have considered the Networking. This concept was introduced by Lev (2000), and points out the company's ability to undertake links and agreements on collaboration in an extensive network of companies, which encompasses the whole world. In this sense, companies are immersed in a global environment, and they shall establish strategic alliances to increase their distribution net to survive. In the development of this global market, Internet can play an important role. For that reason, we have considered the disclosure of information about global activities, especially those dealing with the investments carried out for the establishment of e-business and business-to-business (B2B).

2. Navigation. This second category alludes to the effort realised by companies in order to facilitate the access of the information about intangibles disclosed in their Web site. Among other considerations, we have studied if the companies expose in a unique and structured part all the information relative to the Content (as defined and divided before). We have also positively evaluated the presence of some paragraphs disclosing the "late news" which may affect or deal with any of the different aspects of the business'evolution in general, and intangibles in particular. We have also taken into account if this information was available in different languages. Finally, the inclusion of any references to the analysts' report related to the intangibles has highly rated. The Navigation is, in conclusion, a positive factor to measure and improve the transparency of the company's information.

3. Design ANd ACCessibility. The design of a Web site is a determining factor to explain if the visitor feels attracted or not by its contents. A structured appearance, aesthetically attractive, that is, colourful, with a good combination of graphics and images. The use of several is also very important, as it facilitates the presentation and increases the possibilities for an internet visitor to access frequently to the web site.

To sum up, we have checked if the categories and sections we have just defined were disclosed or presented in the information provided in Internet by the 
companies considered in our study. Every item scored one point if it was included in the Web site, or zero in the opposite case. Nevertheless, when the information has been considered more relevant or useful, we have applied scores superior to one, as we show in figure 1 . The indexes proposed in our study are constructed from the aggregation of those different scores (see appendix 1).

\subsection{An Explanatory Model of Internet Intangibles Disclosure Levels: Variables and Hypothesis}

The academic literature picks up several hypothetical incentives for voluntary disclosure. Companies behavior towards the disclosure of voluntary information may be explained by using different economic theories, such as: agency, signalling and proprietary cost, as well as political costs theory (see Healy and Palepu, 2001, for an overview). These theories could be of special relevance in an Internet disclosure environment as there is no legal duty for companies to provide information through this means. Furthermore, the disclosure on the Internet of compulsory information can be considered as a voluntary disclosure practice in itself (Bonsón and Escobar, 2002).

In general, the relevant variables used to explain the different extents of voluntary disclosure information are referred to several characteristics of the company, such as: size, listing status, nationality, leverage, industry or profitability.

\section{Dependent Variables}

In this study, dependent variables are the different indexes that we have calculated in the previous section (see figure 1). These eight disclosure indexes score for each company and they are additive and unweighted (see appendix 1) in order to remove the subjectivity that usually involves the assignment of weights ${ }^{7}$.

\section{Explanatory Variables}

The independent variables used in our model have been classified in two groups. The first one includes those that explain the voluntary disclosure information. The second one, encloses those referred to intangible assets.

\footnotetext{
$7 \quad$ Unweighted scores have been used in other empirical studies of voluntary disclosures (e.g. Cooke, 1989; Meek et al., 1995; Ettredge et al., 1999b).
} 


\section{Voluntary disclosure models variables}

\section{- Company Size}

Several disclosure studies (see Cooke, 1991; Lang and Lundholm, 1993; Hossain et al., 1995; Meek et al., 1995; Raffournier, 1995; Depoers, 2000) have concluded that the company size is an important factor when explaining the variability in the extent of corporate voluntary disclosure. Usually, large firms disclose more information than small ones. This fact can be caused by different factors. On the one hand, the information production costs may be lower in larger firms. Hence, an accrual of the disclosure will reduce agency costs and information asymmetries in those firms. On the other hand, large organisations are increasing complex, so they may need more disclosure to be placed in the same position as smaller or less complex ones. In this sense, the agency theory suggests that large firms present higher agency costs, but also that they are more sensitive to political costs (Jensen and Meckling, 1976; Watts and Zimmerman, 1990).

Thus, a positive association between firm size and the extent of corporate voluntary disclosure can be predicted. Furthermore, in relation to research about corporate reporting on Internet, the empirical evidences (see Craven and Marston, 1999; Debreceny et al., 1999; Ettredge et al., 1999b; Pirchegger and Wagenhofer, 1999; Bonsón and Escobar, 2002; Larrán and Giner, 2002) show that there is a positive and significant association between company size and the extent of corporate disclosure on the Internet.

All these arguments lead to the first hypothesis of this study:

H1: The extent of internet intangibles disclosure is positively associated with the firm size.

The size of a company can be measured by different ways (sales, number of employees, total assets, company's market capitalization, among others). In this study, size was measured by company's market capitalization at end of 1999, converted into US\$.

\section{- Industry}

As noted Verrecchia (1983), propietary costs vary across industries. For example, because of the nature of their products and their research and 
development, some sectors of the sample (information technology, health car, industrials or materials) are likely to be more sensitive about disclosures to competitors and the public than companies in certain other industries. Empirical evidence shows that there is weak association between the industry effect and the voluntary disclosure (see Cooke, 1989, 1991; Meek et al., 1995). Nevertheless, the results of the research in Internet reported by Lymer (1997) and Bonsón and Escobar (2002) also suggest that there may be an industry effect on Internet disclosure. Thus, the second hypothesis tested was:

H2: The extent of internet intangibles disclosure is associated with the company's industry.

The company's industry classification is based on the industry classification of Standard and Poor's.

\section{- Leverage}

When the company's indebtedness increases in relation to equity, the levels of disclosure will also have to be enlarged, in order that its debtors may be completely confident on its ability to pay them (Watts and Zimmerman, 1990). Nevertheless, the empirical studies have not supported this hypothesis. Chow and Wong-Boren (1987), Hossain et el. (1994, 1995), Meek et al. (1995) and Raffournier (1995) found no significant relation between leverage and voluntary disclosure. In our study, the degree of leverage was measured by the company's debt-to-equity, at end of 1999. Consequently, the third hypothesis tested was:

H3: The extent of internet intangibles disclosure is associated positively with the company degree of leverage.

- $\quad$ Region of Origin

The national or regional variations in the financial reporting requirements are well documented (see, for an overview, Saudagaran, 2001). These differences can also be appointed to explain the disparity in the voluntary disclosure levels, especially those regarding nonfinancial and social items. In this sense, Meek et al. (1995) found that voluntary information disclosures (strategic, nonfinancial and financial) also reflect national/regional influences, with Continental European and British multinational corporations disclosing more than U.S. multinational 
corporations. Their conclusions supports Mueller et al. (1994), who observed that such disclosures are more developed in Europe than in the United States.

All these arguments lead to the fourth hypothesis of this study:

H4: The extent of internet intangibles disclosure is different between European and U.S. multinational corporations.

In the European Context, the results of Bonsón and Escobar (2002) show that the company's country of origin influences the level of information provided on Internet.

\section{Financial Intangibles variables}

\section{- Book-to-Market Ratio (BM)}

Empirical studies have consistently demonstrated the existence of a positive association between the BM ratio and subsequent stock returns (see Chan et al., 1991; Fama and French, 1992; Lakonishok et al., 1994, among others). The economic theory postulates that companies market values differ from their book (equity) values by the present value of their future abnormal earnings. As noted Lev and Sougiannis (1999), abnormal earnings are the result of a monopoly power or a more frequently innovation. Lev and Sougiannis (1999), evidenced empirically that in firms intensive in $R \& D$, the $R \& D$ capital subsumes the book-to-market effect. In other words, in these firms the BM ratio is no longer associated with subsequent returns. In our study, we will suppose that low BM ratio companies have a large Internet intangible disclosure index. This hypothesis assumes that companies with a low BM ratio should disclose additional information about their intangibles, in order to provide more data to facilitate or make possible the investors' decisions making. In this study, BM ratio was measured at end of 1999.

Consequently, the hypothesis tested was:

H5: The extent of internet intangibles disclosure is associated negatively with the $\mathrm{BM}$ ratio of the companies.

- Intangibles Expenditures Intensity

Empirical evidence have demonstrated the existence of a positive association beetwen the intangibles expenditures intensity and the profitability, the earnings 
forecasting or the perfomance of the firms (see Chauvin and Hirschey, 1993; Sougiannis, 1994; Lev and Sougiannis, 1996; Hansson, 1997; Hand, 1998; Huselid, 1999). According to those conclusions, we have considered that the greater the amounts invested by companies in intangibles are, the greater utility or use will provide the financial reports for investors. If investors know the firms' policies in intangibles extensively, their calculus of the companies' market value and, in turn, their process of decisions making will significantly improve.

All these arguments lead to the sixth hypothesis of this study:

H6: The extent of internet intangibles disclosure is associated positively with the intensity of the companies' intangibles expenditures.

Three proxy variables have been used to estimate the intensity of intangibles investment in empirical studies (Lev and Sougiannis, 1996): the R\&D spending to sales, the marketing expenses to sales, and the staff costs (wages, salaries and pensions) to sales. All variables were measured at end of 1999.

\section{- Global Impact of Information Technology and Internet Adoption}

The Internet is in widespread use in almost all the developed countries, and in many developing countries. However, this increase does not necessarily take place across countries. Usually, the supply and use of the Internet as a mean of communication is measured in terms of Internet penetration (see Debreceny et al., 1999). In this paper, the variable that we have chosen is the information society index (IDC/World Times ISI), as elaborated by International Data Corporation (IDC) and World Times ${ }^{8}$. This index qualifies, in 55 countries, the capacity to access to telecommunications networks, and to generate contents for the new information society. In its elaboration, 23 categories are taken into account. In turn, these categories are evaluated and grouped into three sections: the infrastructure in Internet, the infrastructure in telecommunications, and the sociopolitical context. The ISI constitutes an standard measure to compare all countries

\footnotetext{
8 For a more detailed report of their production or to consult the 2000 ISI Rankings, see: [http:// www.idc.com:8080/Data/Global/ISI/ISIMain.htm].
} 
according to their ability to access and assimilate the information and its technology.

In this study, we determine if the Internet intangibles indexes of the multinational corporations change across countries according to the level of development of the information society in a country.

Therefore, it is hypothesized that:

H7: The extent of internet intangibles disclosure is positively associated with the information society development in a country.

\subsection{Sample and Data Collection}

The sample of this study was selected from the Standard \& Poor's Global 100 Index at July of 2000 (see appendix 2). Its composition was shaped by several factors. First, data are collected from multinational corporations, with a global management of their decisions. These corporations are located in 16 countries, in order to assure an international perspective of the problem analysed. Second, these companies belong the 9 economic sectors in which they were to be expected to have significant amounts on the intangibles investments ${ }^{9}$. Finally, the companies chosen are the world's largest 100 companies, and they have a larger proportion of foreign stakeholders in the corporation, and list their shares on different stock exchanges around the world. These three reasons support the argument that in a multinational context, the extent of the information required is expected to increase. This will probably enlarge the level of the voluntary disclosure, especially the Internet disclosure information.

The most representative characteristics of the sample, the number of companies by country and industry (based on the Standard and Poor's classification), are illustrated in table 1. As it can be infer, US and European companies predominate in this sample.

\footnotetext{
9 In Aboody and Lev (1999), the relationship between the sectors of activity and the size of the companies with the intensity of investment in R\&D is statistically documented.
} 


\begin{tabular}{l|l}
\hline \multicolumn{1}{c|}{ NATIONALITY } & \multicolumn{1}{c}{ INDUSTRY } \\
\hline USA (39), Japan (12), United Kingdom & Consumer Discretionary (21); Information \\
(11), Germany (8), France (7), Switzerland & Technology (19); Financials (15); \\
(5), Spain (3), Canada (3), Netherlands (3), & Consumer Staples (11); Health Care (9); \\
Italy (2), Australia (2), Sweden (1), Finland & Telecommunications Services (8); Energy \\
(1), Mexico (1), Belgium (1), Korea (1) & (6); Materials (6); Industrials (5) \\
\hline
\end{tabular}

Table 1. Characteristics of the S\&P Global 100 companies

The data collection was obtained from two sources. First, they were obtained from the Web sites of S\&P GLOBAL 100 companies throughout July of 2000. To quantify the Internet intangibles disclosure indexes, a standardised checklist was applied to each corporate Web site (figure 1). The results of scores of internet, as noted Debreceny et al. (1999), given the range of options open to corporations and the lack of standards, the measurement of Internet disclosure is not an exact science. Hence, we have consulted two independent research assistants to assign scores, in order to reduce the inherent subjectivity involved in the analysis of the contents. The results (see appendix 2) were cross-validated, and the percentage agreement between the two coders was nearly of $95 \%$. These results are similar to others disclosure studies index (see Bhojraj et al., 2000). Second, we have obtained the financial data of those companies at the end of 1999 in the EXTEL database. Financial data were necessary to measure some independent variables of the explanatory model of Internet intangibles disclosure levels.

\subsection{Descriptive Results}

The survey of the web sites demonstrated that companies' Internet intangible disclosure range at a medium level in relation to their innovative and commercial capacity (see table 2). In fact, practically half of them disclose the level of expenditure in $\mathrm{R} \& \mathrm{D}$, but only $13 \%$ disclose historical data about its temporal evolution, and only $19 \%$ indicate the intensity of said investment. However, nearly $50 \%$ of the companies supply information about the evolution of their current $\mathrm{R} \& \mathrm{D}$ projects.

The results exhibit in table 2 also indicate that companies seem reticent to supply information about their innovation and commercialisation figures, such as the inscription of patents, the registered marks or the sales licenses conceded. Finally, we must point out that we did not find any information referred to the 
royalties incomes obtained by the companies studied. And this factor was significantly relevant in our theoretical exposition.

\begin{tabular}{|c|c|c|c|}
\hline \multicolumn{2}{|l|}{ INNOVATION } & \multicolumn{2}{|c|}{ HUMAN RESOURCES } \\
\hline Expenditure invested in $R \& D$ & $48 \%$ & $\begin{array}{l}\text { Number of company employees } \\
\text { Proportion of graduates }\end{array}$ & $\begin{array}{l}60 \% \\
22 \%\end{array}$ \\
\hline Intensity in $\mathrm{R} \& \mathrm{D}$ & $19 \%$ & Proportion of scientifically & \\
\hline $\mathrm{R} \& \mathrm{D}$ Projects underway & $48 \%$ & $\begin{array}{l}\text { trained staff } \\
\text { Employee training plans }\end{array}$ & $\begin{array}{l}20 \% \\
62 \%\end{array}$ \\
\hline $\begin{array}{l}\text { Description of } R \& D \text { centres } \\
\text { Collaboration with Basic }\end{array}$ & $47 \%$ & Promotion schemes & $31 \%$ \\
\hline investigation centres & $43 \%$ & Retribution schemes & $38 \%$ \\
\hline Patents filed & $40 \%$ & Personnel selection process & $62 \%$ \\
\hline Marks registered & $40 \%$ & Mean employee age & $1 \%$ \\
\hline Sales licences conceded & $33 \%$ & Mean employee seniority & $1 \%$ \\
\hline Royalty income & $0 \%$ & & \\
\hline \multicolumn{2}{|l|}{ CUSTOMERS } & \multicolumn{2}{|l|}{ NETWORKING } \\
\hline Products commercialised & $98 \%$ & Signing of strategic alliances & $62 \%$ \\
\hline $\begin{array}{l}\text { Dimensions and characteristics } \\
\text { of branch network }\end{array}$ & $93 \%$ & Distribution network & $69 \%$ \\
\hline Product and service quality control & $79 \%$ & $\begin{array}{l}\text { Collaboration with other } \\
\text { companies }\end{array}$ & $62 \%$ \\
\hline Guarantees offered & $56 \%$ & $\mathrm{~B} 2 \mathrm{~B}$ & $27 \%$ \\
\hline Integral after sales service & $63 \%$ & e-business & $73 \%$ \\
\hline Company "philosophy" & $71 \%$ & & \\
\hline
\end{tabular}

Table 2. Summary of Intangibles Information on the Internet by S\&P Global 100 companies.

The analysis of the second section shows that the level of the information revealed about human resources could be qualified as medium-low. Practically two-thirds of the companies include information about this professional career. But most of this information is related to the employment offered by the company. This information is usually provided in order that the firm's employees knew, not only the characteristics of the jobs offered, but also the region or country in which they are offered. Those information facilitate their geographical movement. It also concerns the recruitment of new staff .

The information dealing with customers presents the highest levels of extent, as we can deduce of the study of the third section. This observation may be explained by the fact that the Internet's commercial aspects were and are still 
emphasised in its initial and current development stage. As is evinced in table 2, nearly all the companies use their web sites to offer information about the goods/ services they supply, and about the dimensions and characteristics of their branch or filial networks throughout the world. The information revealed about the quality controls and the guarantee services may be also considered as positive.

Finally, in the analysis of networking, we have observed that the levels of disclosure can be qualified as medium-high. In effect, they score around the 70\% in almost all of the cases. However, the establishment of B2B agreements is the only section in which we have detected a less open informative policy. This situation may be caused by the strategic but novel character this extent has for many companies.

The results of the individual items of the "navigation Internet index" denote that companies have mostly (92\%) been aware of the convenience to disclose in an specific and separate paragraph some information about their commercial characteristics. But it seems to be a lesser consensus to include notes about human resources (68\%) and innovation (54\%).

This disparity is not observed in the values of the items composing the "designaccessibility Internet index". Actually, the results obtained present an indeed homogeneity, with levels very close to $100 \%$ in all the companies. The support graphics are, nevertheless, the only exception: only $21 \%$ have made use of this recourse.

\subsection{Statistical Analysis}

The statistical analysis have processed eight models of multiple regression, one for each Internet disclosure index. For the estimation of the regression models, we removed of the sample the 15 financial companies of S\&P Global 100. With the remaining 85 firms, we used the following regression model:

$D=c+\beta_{1} S+\beta_{2} I_{1}+\beta_{2} l_{2}+\beta_{4} I_{2}+\beta_{2} L+\beta_{0} R_{1}+\beta_{2} R_{2}+\beta_{2} B M+\beta_{2} S C l+\beta_{10} M K I+\beta_{11} R D I+\beta_{12} G I+c$

where

Dependent variables

D Internet disclosure indexes (ln): IT, IC, IN, IHR, ICS, INTW, INVT, IDA 
Voluntary disclosure models variables

S Company size (ln)

I Industry

$\mathrm{I}_{1}$ Information technologies and telecommunications

$\mathrm{I}_{2}$ Health care and Consumer staples

$\mathrm{I}_{3}$ Energy, Materials and Industrials

L Leverage (ln)

$\mathrm{R} \quad$ Region of origin

$\mathrm{R}_{1} \quad$ United States of America

$\mathrm{R}_{2}$ Europe

Financial intangibles variables

BM Book-to-Market ratio (ln)

SCI Staff Costs expenses intensity (ln)

MKI Marketing expenses intensity (ln)

RDI R\&D expenses intensity (ln)

GII Global impact of information technology (ln)

Other Terms

$\mathrm{c}, \beta_{1}, \ldots . ., \beta_{12}$ Coefficients to be estimated

$\varepsilon$ Stochastic disturbance term: the part of $D$ not explained by the other explanatory variables

The multiple regression analysis revealed that dependent and independent variables were exponential. Thus, the model was simplified applying a logarithmic transformation, in order to use a OLS regression. This transformation provided a more operative model, with a great explanatory power. The log-transformation was also recommended when the continuous variables were submitted to high levels of skewness and kurtosis, as occurred in our model (see Tabachnick and Fidell, 1996). After the log-transformation, the continuous variables satisfied the normality characteristics ${ }^{10}$.

\footnotetext{
10 Ahmed and Nicholls (1994) recommended normalising raw scores using a logarithm transformation of the odds ratio to avoid estimation problems using OLS regression.
} 
As regarding the statistical issues, we also want to expose that our disclosure model assumes that the dummy variables causes an additive effect on the dependent variables. In this sense, most of the regression studies assume this additive effect as well, because this alternative does not consider the interactivity between two or more continuous variables and dummies variables. In consequence, this assumption reduces the model's complexity. However, the use of ANOVA tests proved that the possible interactions between those two kind of variables were not statistically significant.

The model's postulates were moreover tested in order to study their possible multicollinearity, heteroscedasticity and a non-normal residuals' distribution. The matrix of correlations for eight regressions, were not showing serious problems of multicollinearity between independent variables. On the other hand, BreuschPagan statistic results detected homoscedasticity, and the Kolmogorov-SmirnovLilliefors statistic diagnosed that the residuals' distribution did not differ excessively from a normal distribution.

\subsection{Results}

The multiple regression models' results are presented in table 3 . The percentages of the explained variation in the disclosure intangible indexes ranges from the $14.5 \%$ reached by the Customers index (ICS) to the $37.7 \%$ attained by the Contents index. These values are consistent with those of other similar studies that have also used disclosure indexes (Meek et al., 1995; Raffournier, 1995; Depoers, 2000), and Internet disclosure indexes (Debreceny et al., 1999; Ettredge et al., 1999b; Larrán and Giner, 2002).

H1: SizE. The results were not statistically significant except for the Networking index ( $\mathrm{p} \leq 0,068)$. The absence of a statistically significance might be explained by the sample chosen, which was composed only for the world's largest companies. Nevertheless, the signs of the expected relationships were positive, as we had predicted. They corroborate that large firms disclose more corporate voluntary information in Internet, and particularly information about their intangibles.

H2: InduSTRY. In general, the company's industry has presented a weak association with the intangibles Internet indexes. In fact, only the Customers 


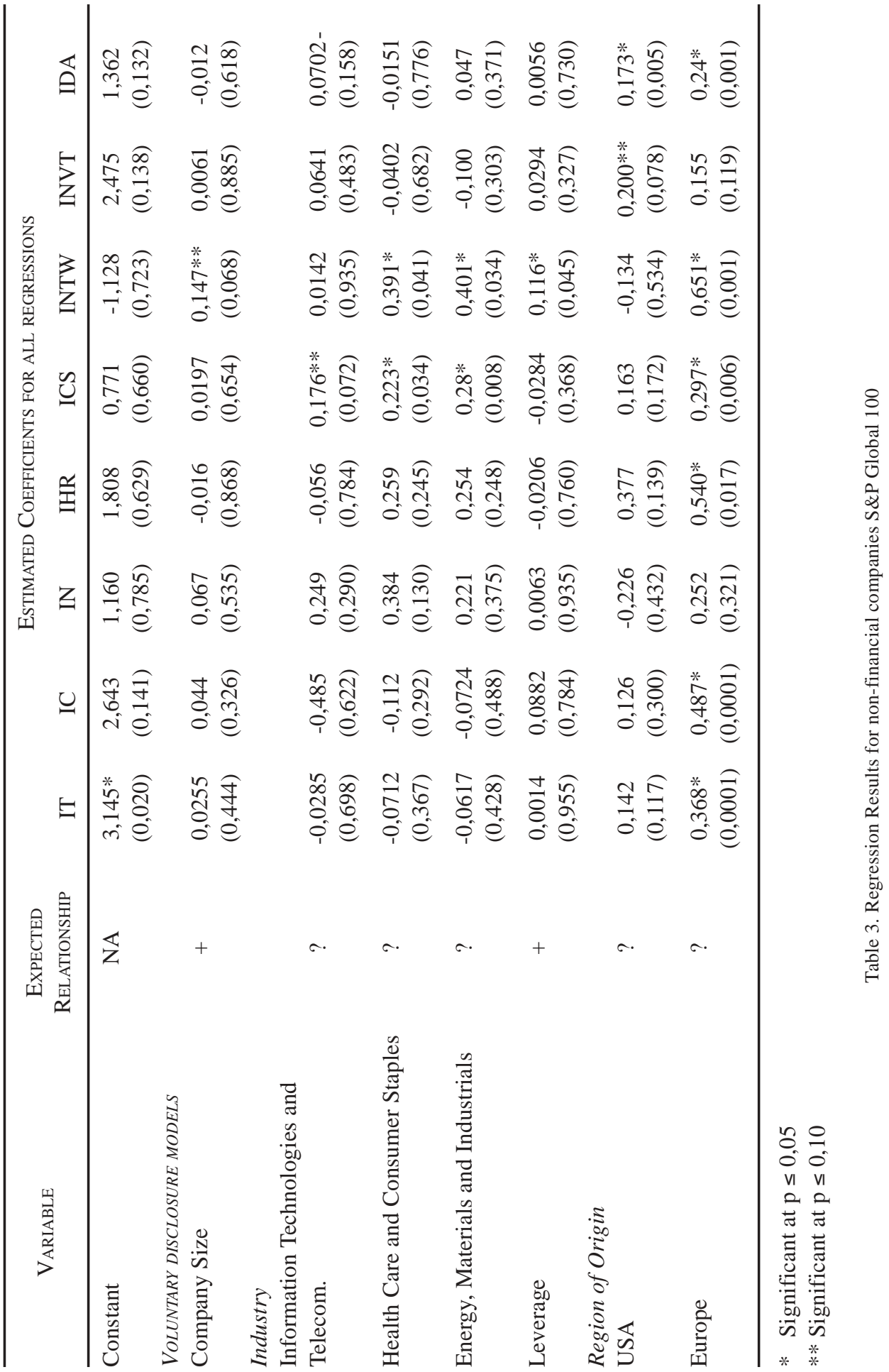




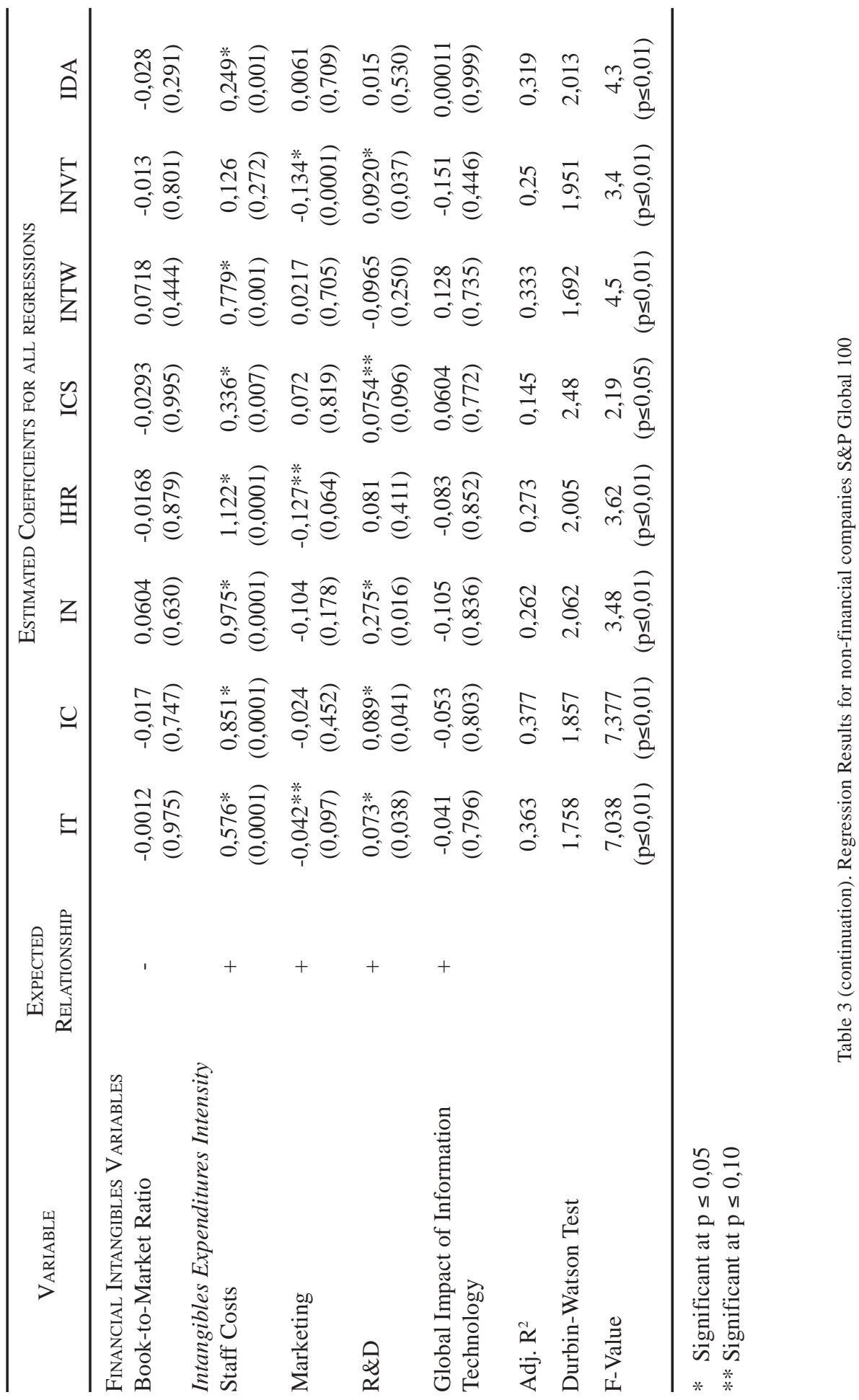


index (ICS) is significant in all the sectors analysed. Likewise, companies classified in the health care and consumer staples, and in the energy, materials and industrial present coefficients that are significant with the Networking index (INTW). The observations may be interpreted bearing in mind that, nowadays, companies still emphasise only or basically the commercial and business possibilities that Internet offers.

H3: Leverage. In all the regressions, the signs of the estimated coefficients were positive, as it has been predicted. These results conclude that the more highly levered a company is, the more information is likely to provide. However, the results were not statistically significant except for the Networking index $(\mathrm{p} \leq 0,045)$. In this sense, it seems highly probable that firms with established alliances and strategic agreements with other companies should offer more information, especially if they have assumed important financial debt risks.

H4: Region of Origin. The region of origin is statistically significant for all the intangibles Internet indexes, except the innovation (IN) and navigation (INVT) ones, in all the European companies studied. These results reveal that European multinational companies provided more intangibles information through Internet than US multinational companies. In this sense, they confirm Meek et al. (1995), who concluded that this observation was particularly noticeable in the items referred to strategic questions, a characteristic attributable to the information about intangibles disclosed by the companies through Internet.

H5: Book-to-Market Ratio. The results were not statistically significant. However, the signs of the expected relationship were negative, as predicted. This supports the opinion that companies with a low BM ratio should disclose additional information about their intangibles, in order to grant or to ameliorate the investors decisions making. In this sense, it is important to point that companies use also other mass media to report information about intangibles. But they do not offer the additional advantages Internet will put at the companies' disposal soon.

H6: IntAngibles Expenditures InTEnSITy. These explanatory variables were the most statistically significant, especially, the staff costs and $R \& D$ 
investment. These variables were statistically significant in the contents Internet intangibles index (IC). Furthermore, in total Internet intangibles index (IT), these variables, close to marketing expenses, were statistically significant. These results corroborate the empirical evidence that the greater the amounts invested in intangibles are, the greater will be the propensity that companies will induce to disclose this kind of information.

\section{H7: Global Impact of Information Technology and Internet Adoption.} This explanatory variable was not statistically significant. This implies that in spite of the differences in the level of the information society's development, there are no differences between countries in the Internet disclosure indexes. This result is logical, if we consider that S\&P Global 100 companies have transcended their respective nationalities. If they compete head to head on a global basis for resources, customers, etc, then there are few reasons to expect that, for example, a Mexican company would be is less developed than other company in terms of its Internet disclosures.

\section{CONCLUSIONS}

Modern information technology is creating a new corporate communication landscape. It is affecting communication channels, corporate audience identification, mode and methods of communication, message content and form and communication feedback. Computer technology has altered the power structure and the relationship between corporations and their publics, stakeholders and the media. In recent years there has been an explosive growth in the use of the Internet. Many companies have set up Web sites and these have been used for the dissemination of business information. This type of disclosure is voluntary and, at the moment, unregulated.

In this paper, we have examined the extent and the way companies use Internet to provide information about their intangibles. The Internet intangible disclosure indexes has emphasized the business heterogeneity that exists on this subject. In fact, the lack of structure of some of the companies'web sites is the main criticism that we can make. We also want to point that it has complicated the data's procurement. The absence of contents or their unstructured presence reduced the utility of the Web sites as channels to disclose information about intangibles. 
However, the evidence obtained reaffirms the potential that Internet has as useful mechanism for improving the communication between the companies which have generated the intangible information and its potential users.

Our empirical research has evidenced the existence of a positive association between the region of origin, the intensity of intangibles expenditures, and the Internet intangible disclosure indexes. Concretely, European companies' indexes have scored higher than US', aspect that confirms other empirical evidence about voluntary disclosure information. We have also detected that the higher the intangibles expenditures intensity are, the more information is disclosed through Internet. In consequence, our proposed indexes set up as a valid mechanism to discriminate the companies included in the S\&P Global 100 and to reveal the authentic level of commitment that companies assume concerning the information about intangibles.

However, the results must be interpreted in the light of limitations the study. Firstly, the sample of companies is constituted by the largest companies all over the world. Secondly, the intangible classification adopted by Web sites data collection. Finally, the measurement of Internet disclosure is not an exact science. Future researches, could involve a wider sample population, and other intangibles classifications. In addition, future research could examine the Internet implications by different models of intangibles statements disclosure, especially, intellectual capital statement.

\section{REFERENCES}

ABOODY, D.; LEV, B. (1998): "The value relevance of intangibles: the case of software capitalization", Journal of Accounting Research, vol. 36 supplement: 161-191.

ABOODY, D.; LEV, B. (1999): "R\&D and insider gains", Working Paper. New York University, available at: http://www.stern.nyu.edu/ blev/

AHMED, K.; NICHOLLS, D. (1994): "The impact of non-financial company characteristics on mandatory disclosure compliance in development countries: the cases of Bangladesh", The International Journal of Accounting, vol. 29: 62-77. 
AICPA - American Institute of Certified Public Accountants (1994): Improving business reporting - a customer focus: meeting information needs of investors and creditors. Comprehensive Report of the Special Committee on Financial Reporting, available at: http://www.aicpa.org/members/div/acctstd/ibr/index.htm

ARORA, A.; FOSFURI, A.; GAMBARDELLA, A. (2000): "Markets for technology and their implications for corporate strategy", Working Paper. Carnegie Mellon University, available at: http://www.heinz.cmu.edu/heinz/faculty/ Arora.html

ASHBAUGH, H.; JOHNSTONE, K.M.; WARFIELD, T.D. (1999): "Corporate reporting on the Internet", Accounting Horizons, vol. 13: 241-257.

BEATTIE, V.; PRATT, K. (2001): "The delivery and structure of business reporting information in the Internet age: the views of interested parties", Working Paper, Departament of Accounting, Finance and Law, University of Stirling.

BHOJRAJ, S.; BLACCONIERE, W.G.; D’SOUZA, J. (2000): "Voluntary disclosure in a multi-audience setting: an empirical investigation", Working Paper, Cornell University, Ithaca.

BONSÓN, E.; ESCOBAR, T. (2002): “A survey on voluntary disclosure on the Internet. Empirical evidence from 300 European Union companies", The International Journal of Digital Accounting Research, vol. 2: 27-51.

BOTOSAN, C.A. (1997): "Disclosure Level and the Cost of Equity Capital", The Accounting Review, vol. 72: 323-349.

CAÑIBANO, L.; SÁNCHEZ, M.P. (1998): Measuring intangibles to understand and improve innovation management. A research proposal. Madrid: Universidad Autónoma.

CAÑIBANO, L.; GARCÍA-AYUSO, M.; SÁNCHEZ, M.P. (2000): “Accounting for Intangibles: A Literature Review”, Journal of Accounting Literature, vol. 19: 102-130.

CHAN, L.; HAMAO, Y.; LAKONISHOK, J. (1991): "Fundamentals and stock returns in Japan", Journal of Finance, vol. 46: 1739-1764. 
CHAUVIN, K.W.; HIRSCHEY, M. (1993): “Advertising, R\&D expenditures and the market value of the firm", Financial Management, number 4: 128-140.

CHOW, C.W.; WONG-BOREN, A. (1987): "Voluntary financial disclosure by Mexican corporations", The Accounting Review, vol. 62: 533-541.

COOKE, T.E. (1989): "Voluntary corporate disclosure by Swedish companies", Journal of International Financial Management and Accounting, summer: 171195.

COOKE, T.E. (1991): "An assessment of voluntary disclosure in the annual reports of Japanese corporations", The International Journal of Accounting, vol. 26: 174189.

CRAVEN, B.M.; MARSTON, C.L. (1999): "Financial reporting on the Internet by leading UK companies", The European Accounting Review, vol. 8: 321-333.

DEBRECENY, R.; GRAY, G.; RAHMAN, A. (1999): "Voluntary financial reporting on the Internet: an international perspective",Working Paper. Nanyang Technological University.

DELLER, D.; STUBENRATH, M.; WEBER, C. (1999): “A survey on the use of the Internet for investor relations in the USA, the UK and Germany", The European Accounting Review, vol. 8: 351-364.

DEPOERS, F. (2000): "A cost-benefit study of voluntary disclosure: some empirical evidence from French listed companies", The European Accounting Review, vol. 9: 245-263.

EDVINSSON, L.; MALONE, M.S. (1997): Intellectual capital. Harper Business.

ETTREDGE, M.; RICHARDSON, V.J.; SCHOLZ, S. (1999a): “The presentation of financial information at corporate web sites", Working Paper. University of Kansas.

ETTREDGE, M.; RICHARDSON, V.J.; SCHOLZ, S. (1999b): "Determinants of voluntary dissemination of financial data at corporate web sites", Working Paper. University of Kansas. 
FAMA, E.; FRENCH, K. (1992): “The cross-section of expected returns”, Journal of Finance, vol. 47: 427-465.

FASB - Financial Accounting Standards Board (2000): Electronic Distribution of Business Reporting Information, Steering Committee Report Series. Business Reporting Research Project, available at: http://accounting.rutgers.edu/raw/fasb/ brrp/brrp2.html

FASB - Financial Accounting Standards Board (2001a): Improving Business Reporting: Insigths into Enhancing Voluntary Disclosures, Steering Committee Report Series. Business Reporting Research Project, available at: http:// accounting.rutgers.edu/raw/fasb/brrp/brrp2.html

FASB - Financial Accounting Standards Board (2001b): Business and Financial Reporting, Challenges from the New Economy, Special Report. Available at: http:/ /accounting.rutgers.edu/raw/fasb/sr_new_economy.pdf

FRANCIS, J.; SCHIPPER, K. (1999): "Have financial statements lost their relevance?", Journal of Accounting Research, vol. 37: 319-352.

GANDÍA, J.L. (2001): La divulgación de información financiera en la era digital, Madrid, Asociación Española de Contabilidad y Administración de Empresas (AECA).

GOWTHORPE, C.; AMAT, O. (1999): "External reporting of accounting and financial information via the Internet in Spain", The European Accounting Review, vol. 8: 365-371.

GRAY, G.L.; DEBRECENY, R. (1997): "Corporate reporting on the Internet: Opportunities and Challenges" Paper presented at the Asia-Pacific Conference on International Accounting Issues, Bangkok.

GRÖJER, J.E. (2001): "Intangibles and accounting classifications: in search of a classification strategy", Accounting, Organizations and Society, vol. 26: 695-713.

GU, F.; LEV, B. (2000): “Markets in intangibles: patent licensing” Working Paper. New York University, available at: http://www.stern.nyu.edu/ blev/ 
GUTHRIE, J.; PETTY, R.; JOHANSON, U. (2001): "Sunrise in the knowledge economy. Managing, measuring and reporting intellectual capital", Accounting, Auditing and Accountability Journal, vol. 14: 365-382.

HAND, J. (1998): “Does CEO human capital make a difference?", Working Paper, University of North Carolina.

HANSSON, B. (1997): "Personnel investments and abnormal return: knowledgebased firms and human resource accounting", Journal of Human Resources Costing and Accounting, vol. 2: 9-29.

HEALY, P. M.; PALEPU, K.G. (2001): "Information asymmetry, corporate disclosure, and the capital markets: a review of the empirical disclosure literature", Journal of Accounting and Economics, vol. 31: 405-440.

HEDLIN, P. (1999): "The Internet as a vehicle for investor relations: the Swedish case", The European Accounting Review, vol. 8: 373-381.

HOSSAIN, M.; PERERA, H.B.; RAHMAN, A.R. (1995): "Voluntary disclosure in the annual reports of New Zealand companies", Journal of International Financial Management and Accounting, vol. 6: 69-87.

HUSELID, M. (1999): "Human resources, knowledge management and firm's performance", Working Paper, Rutgers University.

ICAEW - The Institute of Chartered Accountants in England and Wales (1998a): Performance measurement in the digital age, London.

ICAEW - The Institute of Chartered Accountants in England and Wales (1998b): The $21^{\text {st }}$ century annual report, London.

ICAEW - The Institute of Chartered Accountants in England and Wales (1999): Inside Out: reporting on shareholder value, London.

JENSEN, M.; MECKLING, W. (1976): "Theory of the firm: managerial behaviour, agency costs and ownership structure", Journal of Financial Economics, vol. 3: 305-360. 
JOHANSON, U.; MARTENSSON, M.; SKOOG, M. (2001): "Mobilizing change through the management control of intangibles", Accounting, Organizations and Society, vol. 26: 715-733.

JOHANSON, U.; EKLÖV, G.; HOLMGREN, M.; MARTENSSON, M. (1999): Human resource costing andaAccounting versus the BSC. A literature survey of experience with the concepts (A report to OECD). Stockholm University, School of Business (Working Paper).

KAPLAN, R.S.; NORTON, D. P. (1992): “The balanced scorecard measures that drive performance", Harvard Business Review, vol. 70: 71-79.

LAKONISHOK, J.; SHLEIFER, A.; VISHNY, R. (1994): "Contrarian investment, extrapolation, and risk", Journal of Finance, vol. 49:1541-1578.

LANG, M.; LUNDHOLM, R. (1993): "Cross-sectional determinants of analyst ratings of corporate disclosures", Journal of Accounting Research, vol. 31: 246271.

LARRÁN, M.; GINER, B. (2002): “The use of the Internet for corporate reporting by Spanish companies", The International Journal of Digital Accounting Research, vol. 2: 53-82.

LEV, B. (2000): "New accounting for the new economy", Working Paper. New York University, available at: http://www.stern.nyu.edu/ blev/

LEV, B.; SOUGIANNIS, T. (1996): "The capitalization, amortization and value relevance of R\&D”, Journal of Accounting and Economics, vol. 21: 107-138.

LEV, B.; SOUGIANNIS, T. (1999): "Penetrating the book-to-market black box: the R\&D effect", Journal of Business Finance and Accounting, vol. 26: 419-449.

LEV, B.; ZAROWIN, P. (1999): "The boundaries of financial reporting and how to extend them", Journal of Accounting Research, vol. 37: 353-385.

LYBAERT, N. (2002): "On-line financial reporting -An analysis of the Dutch listed firms", The International Journal of Digital Accounting Research, vol. 2: 195-234. 
LYMER, A. (1997): "The use of the Internet in company reporting: A survey and commentary on the use of the WWW in corporate reporting in the UK", Paper presented at the British Accounting Association Annual Conference, Birmingham.

LYMER, A. (1999): "The Internet and the future of corporate reporting in Europe", The European Accounting Review, vol. 8: 289-301.

LYMER, A.; DEBRECENY, R.; GRAY, G.L.; RAHMAN, A. (1999): Business reporting on the Internet. A report prepared for the International Accounting Standards Committee, available at: http://www.iasc.org.uk/frame/cen3_26.htm

LYMER, A.; TALLBERG, A. (1997): "Corporate reporting and the Internet - a survey and commentary on the use of the WWW in corporate reporting in the UK and Finland", Paper presented at the 20 th Annual Congress of the European Accounting Association, Graz.

MEEK, G.K.; ROBERTS, C.B.; GRAY, S.J. (1995): "Factors influencing voluntary annual report disclosures by U.S.; U.K. and Continental European multinational corporations", Journal of International Business Studies, vol. 26: 555-572.

MEER-KOOISTRA VAN DER, J.; ZIJLSTRA, S.M. (2001): "Reporting on intellectual capital" Accounting, Auditing and Accountability Journal, vol. 14: 456-476.

MUELLER, G.G.; GERNON, H.; MEEK, G.K. (1994): Accounting: An international perspective. $3^{\text {rd }}$ ed.; Burr Ridge, Ill.: Irwin.

PETTY, R.; GUTHRIE, J. (2000): “Intellectual capital literature review: measurement, reporting and management", Journal of Intellectual Capital, vol. 1: $155-176$.

PIRCHEGGER, B.; WAGENHOFER, A. (1999): "Financial information on the Internet: A survey of the homepages of Austrian companies", The European Accounting Review, vol. 8: 383-395.

RAFFOURNIER, B. (1995): "The determinants of voluntary financial disclosure by Swiss listed companies", The European Accounting Review, vol. 4: 261-280. 
ROSLENDER, R. (1997): "Accounting for the worth of employees: Is the discipline finally ready to respond to the challenge?", Journal of Human Resource Costing and Accounting, vol. 2: 9-26.

SAUDAGARAN, S. (2001): International Accounting: A user perspective, London, South-Western, Thomson Learning.

SEC (2002): Acceleration of Periodic Report Filing Dates and Disclosure Concerning Website Access to Reports. Final Rule, available at: http:// www.sec.gov/rules/final/33-8128.htm

SOUGIANNIS, T. (1994): "The accounting based valuation of corporate R\&D", The Accounting Review, vol. 69: 44-68.

STOLOWY, H.; JENY-CAZAVAN, A. (2001): "International accounting disharmony: the case of intangibles", Accounting, Auditing and Accountability Journal, vol. 14: 477-496.

SVEIBY, K.E. (1997): The new organizational wealth. Managing \& measuring knowledge-based assets. San Francisco: Berrett-Koehler Publishers, Inc.

TABACHNICK, B.G.; FIDELL, L.S. (1996): Using multivariate statistics, $3^{\text {rd }}$ ed. New York, HarperCollins College Publishers.

TRITES, G.D. (1999): The impact of technology on financial and business reporting. Toronto: Research Study, The Canadian Institute of Chartered Accountants.

VERRECCHIA, R.E. (1983): "Discretionary disclosure", Journal of Accounting and Economics, vol. 5: 179-194.

WALLMAN, S.M.H. (1997): "The future of accounting and financial reporting part II: access accounting", Accounting Horizons, vol. 11: 103-116.

WATTS, R.; ZIMMERMAN, J. (1990): "Positive accounting theory: a ten year perspective", The Accounting Review, vol. 65: 131-156. 
WILLIS, M.; TESNIÈRE, B.; JONES, A. (2002): Corporate communications for the $21^{\text {st }}$ Century: a white paper discussing the impact of Internet technologies on business reporting, PriceWaterhouseCoopers.

XIAO, Z.; JONES, M.J.; LYMER, A. (2002): "Immediate trends in Internet reporting", The European Accounting Review, vol. 11: 245-275. 